\title{
Nóbelsverðlaun í læknisfræði fyrir uppgötvun lifrarbólguveiru C
}

Sænska Nóbelsnefndin tilkynnti pann 5. október um verðlaunahafa í lífeðlis- eða læknisfræði árið 2020. Að pessu sinni fengu prír vísindamenn verðlaunin, Bandaríkjamennirnir Harvey J. Alter við National Institutes of Health og Charles Rice við Rockefeller-háskólann í New York og Bretinn Michael Houghton við Alberta-háskólann í Edmonton í Kanada, fyrir að uppgötva lifrarbólguveiru C.

Á heimsvísu eru um 70 milljónir manna smitaðir af lifrarbólgu $C$ veirunni sem veldur langvinnri lifrarbólgu, skorpulifur og lifrarkrabbameini. Talið er að um 400.000 einstaklingar deyi árlega úr pessum sjúkdómi.

Lengi var vitað að til væru tvær megingerðir af smitandi lifrarbólgu. Sú fyrri, sem fékk nafnið lifrarbólga $\mathrm{A}$, veldur bráðri lifrarbólgu en leiðir yfirleitt ekki til varanlegs skaða. Hin gerðin, sem smitast aðallega með blóði og líkamsvessum, getur valdið, gjarnan á löngum tíma, skorpulifur og lifrarkrabbameini. Rannsóknir Baruch Blumberg á 7. áratugnum leiddu til uppgötvunar lifrarbólguveiru B og i kjölfarið varð unnt að skima blóðgjafa fyrir pessari veiru. Fyrir uppgötvun sína fékk Blumberg Nóbelsverðlaunin árið 1976. Pótt umtalsvert drægi úr algengi lifrarbólgu í tengslum við blóðgjafir eftir uppgötvun lifrarbólguveiru $B$ varð fljótt ljóst að áfram var stór hópur blóðpega að veikjast af langvinnri lifrarbólgu.

Á pessum árum beindust rannsóknir Harvey Alters að lifrarbólgu hjá sjúklingum sem höfðu fengið blóð og voru hvorki smitaðir af lifrarbólguveiru A né $B$. Harvey og félagar gátu sýnt fram á að blóð úr pessum sjúklingum gat borið lifrarbólgu í simpansa. Í kjölfarið sýndu rannsóknir peirra að pessi ópekkti sýkill bar öll merki pess að vera veira. Niðurstöðurnar voru birtar árið 1975. ${ }^{1}$ Pessi dularfulli sjúkdómur fékk svo nafnið „,ekki A, ekki B lifrarbólga“ til aðgreiningar frá lifrarbólgu A og B.

Langur tími leið svo frá uppgötvunum Harveys og félaga par til veiran sjálf var einangruð en par kemur Michael Houghton við sögu. Á peim tíma starfaði hann hjá lyfjafyrirtækinu Chiron í Kaliforníu. Michael og rannsóknarteymi hans beittu nýjum aðferðum til að einangra genamengi veirunnar. Eftir protlausa vinnu fundu peir áður ópekkta RNA flavi-veiru sem hlaut nafngiftina lifrarbólguveira C. Tilvist mótefna sem fundust í blóði sýktra benti eindregið til að hér væri fundin veiran sem orsakar „ekki A, ekki B“ lifrarbólgu. Niðurstöður sínar birtu peir í tímaritinu Science árið 1989.2,3

Enn var eftir að sanna að pessi nýuppgötvaða veira gæti orsakað lifrarbólgu. Par kom til kasta Charles M. Rice og félaga sem beittu erfðatækni til að fjarlægja hluta erfðamengis veirunnar sem pá grunaði аð hindraði veiruskiptingu. Pegar pessu nýja RNA-afbrigði var sprautað í lifur simpansa fengu peir langvinna lifrarbólgu svipaða peirri sem pekkt var í mönnum eftir blóðgjöf. ${ }^{4}$ Petta var lokasönnun pess að hin nýuppgötvaða veira væri orsök óútskýrðrar lifrarbólgu hjá blóðpegum.

Uppgötvanir pessara priggja vísindamanna og rannsóknarteyma peirra hafa haft gríðarlega pýðingu. Í kjölfarið var unnt að próa mótefnapróf til greiningar á veirunni. Nú var unnt að skima blóð í blóðbönkum og lifrarbólga eftir blóðgjöf heyrir sögunni til í flestum heimshlutum. Pessar uppgötvanir voru líka forsenda pess að unnt væri að próa lyf gegn veirunni. Pau lyf sem nú eru á markaði hafa valdið byltingu í baráttunni við lifrarbólgu C. Мeð einfaldri töflumeðferð er nú hægt að lækna nánast alla sem smitaðir eru af veirunni.

Pessar framfarir í greiningu og meðferð voru svo forsenda pess að árið 2016 setti Alpjóðaheilbrigðisstofnunin pjóðum heims pað takmark að útrýma lifrarbólgu $\mathrm{C}$ sem meiriháttar heilbrigðisvá fyrir árið 2030. Í pví felst að greina $90 \%$ og meðhöndla $80 \%$ smitaðra með раð аð markmiði að lækka dánartíðni um 65\% og nýgengi um $80 \%$.

Veiting pessara verðlauna er sérstaklega ánægjuleg fyrir okkur hér á Íslandi. Í ársbyrjun 2016 var hrundið af stað meðferðarátaki gegn lifrarbólgu $C$ hér á landi með pað að markmiði að bjóða öllum smituðum lyfjameðferð og lækningu og útrýma lifrarbólgu C sem meiriháttar heilbrigðisvá. ${ }^{5}$ Á fyrstu premur árum átaksins tókst að meðhöndla meira en 95\% allra greindra einstaklinga og stórlækka algengi lifrarbólgu C í helsta áhættuhópnum, sem er fólk sem sprautar sig með vímuefnum í æð. Árangurinn hér á landi og sú nálgun sem við höfum beitt hefur vakið athygli erlendis og skipað Íslandi í sveit forystupjóða í baráttunni við pennan skæða sjúkdóm.

\section{Heimildir}

Feinstone SM, Kapikian AZ, Purcell RH, et al. Transfusion-associated hepatitis not due to viral hepatitis type A or B. N Engl J Med 1975; 292 767-70.

2. Choo QL, Kuo G, Weiner AJ, et al. Isolation of a cDNA clone derived from a blood-borne non-A, non-B viral hepatitis genome. Science 1989; 244: 359-62.

3. Kuo G, Choo QL, Alter HJ, et al. An assay for circulating antibodies to amajor etiologic virus of human non-A, non-B hepatitis. Science 1989; 244: 362-4.

4. Kolykhalov AA, Agapov EV, Blight KJ, et al. Transmission of hepatitis C by intrahepatic inoculation with transcribed RNA. Science 1997; 277 570-4.

Olafsson S, Tyrfingsson T, Runarsdottir V, et al. Treatment as Prevention for Hepatitis C (TraP Hep C) - a nationwide elimination programme in Iceland using direct-acting antiviral agents. J Intern Med 2018; 283: 500-7.

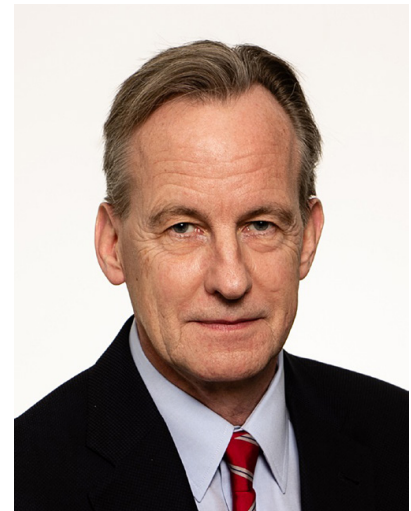

Sigurour Ólafsson

læknir

Sérfræðingur í meltingarog lifrarsjúkdómum á Landspítala og klínískur dósent við læknadeild Háskóla Íslands

sigurdol@landspitali.is

The 2020 Nobel Prize in Physiology or Medicine awarded for the discovery of Hepatitis C virus

Sigurður Ólafsson MD, FACP

Consultant, Division of Gastroenterology and Hepatology, Department of Medicine, Landspitali - The National University Hospital of Iceland Associate Professor of Medicine, University of Iceland Faculty of Medicine

doi 10.17992/lbl.2020.11.604 